\title{
Moths of Bukit Timah Nature Reserve, Singapore
}

\author{
R. Karam \& J.H. Chong \\ Saint Joseph's Institution, 38 Malcolm Road, \\ 308274 Singapore \\ raykaram01@hotmail.com
}

\begin{abstract}
The moth fauna of Bukit Timah Nature Reserve, Singapore, was studied using light trapping. Specimens and photographs were sorted into morphospecies including macro and micro moths. A total of 399 species has been found, of which nearly 200 have been identified to species level. Several are notably rare or otherwise of interest. The figures do not reach an asymptote, suggesting that the total moth fauna may be considerably greater. The nature reserve may be too small to yield statistically significant differences in the moth fauna between forest vegetation zones.
\end{abstract}

Keywords. Biodiversity, insects, Lepidoptera, survey techniques, tropical rain forest

\section{Introduction}

Although Alfred Russel Wallace investigated extensively the fauna and flora of the Malay Archipelago between 1854 and 1862, collecting at least 110,000 insects, including more than 3,000 Lepidoptera (Wallace, 1869), his emphasis was not upon moths. Some moths were mentioned and/or collected by him but not in significant numbers (Wallace, 1869). Except for several months after his first arrival, in 1854, when he was based near what is now Bukit Timah Nature Reserve (BTNR), his trips to Singapore seem to have been largely for practical reasons, such as replenishing supplies, rather than focussing on nature. This is understandable in the context that, relative to the richness of the surrounding islands, Singapore was likely to yield fewer and fewer new species for a given time or effort. It was when in Borneo that he remarked how, after a rainy day in the middle of the forest staying at a house with white washed walls, tens of moths were attracted to the light with up to 260 on the most productive night (Wallace, 1869).

Moths have continued to attract rather little attention in Singapore and have been an adjunct to broader studies by entomologists. Murphy (1973), an avid collector of many invertebrates, focussed primarily on the insect communities of mangroves and lowland forest, including but not highlighting moths. Similarly, professional and amateur entomologists in Singapore have found it more productive to work on moths of neighbouring areas, such as Fraser's Hill and other Malaysian highlands (Barlow, 1982; Leong et al., 2017).

However, Singapore is still rich in biodiversity and, to conserve what still exists, it is very important to maintain public interest, to track species and populations, and to perform ecological studies investigating the variety of fauna and flora in this 
small and densely populated island nation. Moths are of particular interest as they are numerous, readily studied (Beck \& Linsenmair, 2006), closely linked to the plant species and vegetation quality (Kitching et al., 2000), very sensitive to environmental disturbances (Holloway, 1985) and taxonomically diverse (Barlow \& Wowoid, 1989). They can therefore be helpful indicators of environmental quality.

The comprehensive biodiversity survey of the 163 ha BTNR has been introduced by Chan \& Davison (2019). A study of the moths was conducted as part of the survey, and is described here.

\section{Materials and Methods}

The study was carried out between 8 May 2015 and 15 September 2016. Throughout the study, sampling was undertaken between 19:00 - 22:00 hrs.

Light traps were positioned in different parts of the reserve, near Catchment Path, Jungle Fall Path, Lasia Track, Main (Summit) Road and South View Path, to cover primary, old secondary and maturing secondary forest zones. There were no lights within the reserve at night although Singapore experiences a very high degree of night-time illumination exceeding $3000 \mu \mathrm{cd} / \mathrm{m}^{2}$ on all nights (Falchi et al., 2016). A generator was employed to supply the necessary electricity for the light traps. A 150 W UV light bulb was used. A long cable was used to keep the generator away from the trap. The trap itself consisted of the light bulb fixed about $1.5 \mathrm{~m}$ from the ground on a tripod placed about $0.5 \mathrm{~m}$ from a white sheet of material about $2 \times 2 \mathrm{~m}$ hanging over an improvised frame.

The main challenge for this project was the transport of the generator (approx. $20 \mathrm{~kg}$ ). The reserve is quite hilly and the sampling points inaccessible by car. The generator had to be carried by hand across rough terrain and up and down steps. This, combined with the ongoing structural works on the reserve, meant that it was not possible to set up the light trap for equal times at equal spacing across the reserve. For instance, it was a long stretch to carry the generator to the Lasia Track location whilst the Jungle Fall Path was not accessible until 2016. On the other hand, Main Road was the easiest to get to so was visited most frequently.

An attempt was made at every site to position the light trap on paths so that the light could shine up and down the paths to maximise the range of attraction to moths, unobscured by trees and bushes.

Using a light bulb that gets very hot meant that we could not set up the trap when it was raining. The table shows some trapping days when rain had fallen yet this would have only occurred during daytime, not when the trap was operated.

Moths started to be attracted to the light almost half an hour after the set up. Most of the moths that were attracted to the light and settled down on the white sheet were photographed. It was clear at times that some moths passed by and seemed indifferent to the light. Some were attracted yet flew off immediately afterwards. Very few of the moths that failed to settle were caught without being photographed. 
Medium and large moths were collected in vials and placed in a cooler box containing bottles filled with ice. This calmed down the moths without causing much damage to their wings. The vials were later placed in a freezer for a couple of hours and then stored in a refrigerator. After a few days the moths were set and then kept in plastic boxes containing dehumidifiers and sealed with tape to reduce damage to the moths.

A few moths were photographed yet escaped before they could be captured. Others, as mentioned above, did not settle long enough to be photographed and were caught to avoid losing them. Many micromoths were attracted to the light and were photographed yet not captured, as this study was not able to handle and set such small specimens. However, identifications of micromoths from photographs were included in the procedures and totals given below.

The set moths were given the camera/site reference numbers and attempts were made to identify as many of the species as possible using the various available books, especially those of Barlow (1982) and Holloway (1983-2010). Only colour and other external visible characteristics were used. No analyses of genitalia were attempted. Photographs from each location within BTNR were analysed and all duplicates were removed in order to count the number of morphospecies (recognisable taxonomic units). To err on the cautious side, any moths that showed only tiny differences were removed from the count. In 2018, photographs of the set specimens were sent to Henry Barlow who identified most of the samples that are listed in this study. The set specimens were later deposited with the Lee Kong Chian Natural History Museum (LKCNHM), National University of Singapore for DNA barcoding and retention, so that the balance of unidentified material can be identified in future.

\section{Results}

Table 1 shows the number of moth morphospecies counted per location and per session. Having compiled all the photographs and removed any duplicates across all trapping locations it was found that the 22 trapping sessions yielded 399 species of moths (including micro and macro moths). Of these, approaching 200 different species have been named to species level and more than 100 photographs are yet to be identified. The list of taxa identified to date (Table 2) is subject to continuing revision. A few of the species identified are considered rare and are of national or more than national interest (Fig. 1-2).

A comparison of trapping results in primary forest (Catchment Path, Jungle Fall Path, Main Road) versus old secondary (South View) and maturing secondary forest (Lasia Track) does not suggest any significant differences (Table 1). Bearing in mind that moths are mobile, the extent of the forest types and the distances between them are probably too small to show differences within a limited survey effort. Jungle Fall Path had the highest average number of species per session (65, but only three sessions). The Main Road had a rather low average, 35 species per session (average of eight sessions) but attracted in one visit 68 species and at another time only 19. 
Table 1. Trapping statistics for moths at five locations within Bukit Timah Nature Reserve, Singapore. Data on moon and rainfall were supplied by the Meteorological Service Singapore.

\begin{tabular}{|c|c|c|c|c|c|c|}
\hline Locality & $\begin{array}{l}\text { Latitude/ } \\
\text { Longitude }\end{array}$ & $\begin{array}{l}\text { Forest } \\
\text { Vegetation } \\
\text { Type }\end{array}$ & $\begin{array}{l}\text { Dates } \\
\text { Surveyed }\end{array}$ & $\begin{array}{l}\text { Moon Illumination/ } \\
\text { Moon Rise/ Daily } \\
\text { Rainfall* }\end{array}$ & $\begin{array}{l}\text { No. of } \\
\text { species } \\
\text { noted }\end{array}$ & $\begin{array}{l}\text { Average } \\
\text { no. of } \\
\text { species }\end{array}$ \\
\hline $\begin{array}{l}\text { Catchment } \\
\text { Path }\end{array}$ & $\begin{array}{l}1^{\circ} 21^{\prime} 13^{\prime \prime N} \\
103^{\circ} 46^{\prime} 42^{\prime \prime} \mathrm{E}\end{array}$ & $\begin{array}{l}\text { Primary next } \\
\text { to Secondary }\end{array}$ & 8 May 2015 & $\begin{array}{l}85.8 \%, 22: 50 \mathrm{hrs} \\
\text { No rainfall }\end{array}$ & 66 & \\
\hline \multirow[t]{4}{*}{$\begin{array}{l}\text { Collected } \\
112 \text { specimens }\end{array}$} & & & 30 June 2015 & $\begin{array}{l}97.3 \%, 17: 38 \mathrm{hrs} \\
\text { No rainfall }\end{array}$ & 48 & \\
\hline & & & 28 Aug 2015 & $\begin{array}{l}95 \%, 17: 49 \mathrm{hrs} \\
\text { No rainfall }\end{array}$ & 56 & \\
\hline & & & 19 Nov 2015 & $\begin{array}{l}52.4 \%, 13: 02 \mathrm{hrs} \\
\text { No records }\end{array}$ & 26 & \\
\hline & & & 1 April 2016 & $\begin{array}{l}46.6 \%, 01: 20 \mathrm{hrs} \\
\text { No rainfall }\end{array}$ & 31 & 45 \\
\hline $\begin{array}{l}\text { Jungle Fall } \\
\text { Path }\end{array}$ & $\begin{array}{l}1^{\circ} 21^{\prime} 19^{\prime \prime N} \\
103^{\circ} 46^{\prime} 28^{\prime \prime} \mathrm{E}\end{array}$ & Primary & 29 Jan 2016 & $\begin{array}{l}79.1 \%, 23: 18 \mathrm{hrs} \\
3.2 \mathrm{~mm}\end{array}$ & 52 & \\
\hline \multirow[t]{2}{*}{$\begin{array}{l}\text { Collected } \\
126 \text { specimens }\end{array}$} & & & 11 Feb 2016 & $\begin{array}{l}9.9 \%, 09: 24 \mathrm{hrs} \\
\text { No rainfall }\end{array}$ & 71 & \\
\hline & & & 29 April 2016 & $\begin{array}{l}62.8 \%, 00: 06 \mathrm{hrs} \\
6.8 \mathrm{~mm}\end{array}$ & 73 & 65 \\
\hline Lasia & $\begin{array}{l}1^{\circ} 21^{\prime} 02^{\prime \prime} \mathrm{N} \\
103^{\circ} 46^{\prime} 52^{\prime \prime} \mathrm{E}\end{array}$ & $\begin{array}{l}\text { Maturing } \\
\text { Secondary }\end{array}$ & 3 July 2015 & $\begin{array}{l}99.3 \%, 18: 33 \mathrm{hrs} \\
\text { No rainfall }\end{array}$ & 38 & \\
\hline $\begin{array}{l}\text { Collected } \\
33 \text { specimens }\end{array}$ & & & 14 Aug 2015 & $\begin{array}{l}0.3 \% \text {. } 06: 33 \mathrm{hrs} \\
\text { No rainfall }\end{array}$ & 15 & 27 \\
\hline Main Road & $\begin{array}{l}1^{\circ} 21^{\prime} 11^{\prime \prime N} \\
103^{\circ} 47^{\prime} 05^{\prime \prime} \mathrm{E}\end{array}$ & Primary & 17 Apr 2015 & $\begin{array}{l}3.9 \%, 05: 25 \mathrm{hrs} \\
4 \mathrm{~mm}\end{array}$ & 43 & \\
\hline \multirow[t]{7}{*}{$\begin{array}{l}\text { Collected } \\
149 \text { specimens }\end{array}$} & & & 10 July 2015 & $\begin{array}{l}37.2 \%, 01: 45 \mathrm{hrs} \\
17.4 \mathrm{~mm}\end{array}$ & 53 & \\
\hline & & & 2 Sep 2015 & $\begin{array}{l}86.7 \%, 22: 26 \mathrm{hrs} \\
\text { No rainfall }\end{array}$ & 19 & \\
\hline & & & 23 Nov 2015 & $\begin{array}{l}92.4 \%, 16: 33 \mathrm{hrs} \\
\text { No records }\end{array}$ & 25 & \\
\hline & & & 25 Mar 2016 & $\begin{array}{l}98.6 \%, 20: 37 \mathrm{hrs} \\
\text { No rainfall }\end{array}$ & 68 & \\
\hline & & & 13 May 2016 & $\begin{array}{l}47.6 \%, 12: 52 \mathrm{hrs} \\
6.4 \mathrm{~mm}\end{array}$ & 25 & \\
\hline & & & 3 Aug 2016 & $\begin{array}{l}0.2 \%, 07: 11 \mathrm{hrs} \\
14.6 \mathrm{~mm}\end{array}$ & 21 & \\
\hline & & & 15 Sep 2016 & $\begin{array}{l}95 \%, 17: 50 \mathrm{hrs} \\
\text { No rainfall }\end{array}$ & 26 & 35 \\
\hline
\end{tabular}


Table 1. Continuation.

\begin{tabular}{|c|c|c|c|c|c|c|}
\hline Locality & $\begin{array}{l}\text { Latitude } \\
\text { Longitude }\end{array}$ & $\begin{array}{l}\text { Forest } \\
\text { Vegetation } \\
\text { Type }\end{array}$ & $\begin{array}{l}\text { Dates } \\
\text { Surveyed }\end{array}$ & $\begin{array}{l}\text { Moon Illumination/ } \\
\text { Moon Rise/ } \\
\text { Daily Rainfall* }\end{array}$ & $\begin{array}{l}\text { No. of } \\
\text { species } \\
\text { noted }\end{array}$ & $\begin{array}{l}\text { Average } \\
\text { no. of } \\
\text { species }\end{array}$ \\
\hline $\begin{array}{l}\text { South View } \\
\text { Path }\end{array}$ & $\begin{array}{l}1^{\circ} 20^{\prime} 50^{\prime \prime} \mathrm{N} \\
103^{\circ} 46^{\prime} 50^{\prime \prime} \mathrm{E}\end{array}$ & $\begin{array}{l}\text { Old } \\
\text { Secondary }\end{array}$ & 8 Apr 2015 & $\begin{array}{l}89.7 \%, 22: 15 \mathrm{hrs} \\
\text { No rainfall }\end{array}$ & 38 & \\
\hline \multirow[t]{3}{*}{$\begin{array}{l}\text { Collected } \\
67 \text { specimens }\end{array}$} & & & 15 May 2015 & $\begin{array}{l}12.5 \%, 04: 08 \mathrm{hrs} \\
40.2 \mathrm{~mm}\end{array}$ & 45 & \\
\hline & & & 4 Mar 2016 & $\begin{array}{l}29.8 \%, 02: 38 \mathrm{hrs} \\
0.2 \mathrm{~mm}\end{array}$ & 51 & \\
\hline & & & 8 Apr 2016 & $\begin{array}{l}1.0 \%, 07: 38 \mathrm{hrs} \\
\text { No rainfall }\end{array}$ & 32 & 42 \\
\hline
\end{tabular}

Over the two years of research in 2015 to 2016, seven sessions in the period August to November yielded an average of 27 species per session while 15 sessions in the period January to July yielded an average of 54 species per session. Along the Main Road, in September 2015, there were only 19 species and in September 2016 there were 26 species. However, in August 2015, 56 species were noted in the Catchment Path and only 21 in August 2016 in the Main Road location. There is evidently a great deal of stochastic variation. A more extensive study would need to be conducted in one location over several years to establish if a seasonal variation does exist.

No obvious correlation was found between moon rise, the moon phases and rainfall versus the number of moths that were attracted. In regard to moonlight and moon rise, there are many examples of high counts with an almost full moon (e.g. Catchment Path, 56 species in August 2015) but low counts as well (e.g. Main Road, 19 species in September 2015). Besides, Singapore is often cloudy so this is another area that would require further investigation.

The light traps attracted not only moths but other creatures as well. At times, some specific insects were very abundant as if they were synchronised. Mosquitoes seemed to avoid the UV light so once the light is on, they were nowhere to be seen. On the other hand, wasps were the most worrying and had to be placed in the cool box and released at the end of the trapping sessions.

\section{Discussion}

It is encouraging to find that at least 399 species have been recorded in this study and nearly 200 identified, including some rare species. It is uncertain what proportion of Singapore's moth fauna or even the proportion of the Bukit Timah moth fauna this 
Table 2. Provisional identification of moth taxa recorded from Bukit Timah Nature Reserve, Singapore, in 2015-2016.

\begin{tabular}{|c|c|}
\hline Family: Subfamily & Species \\
\hline \multirow[t]{2}{*}{ Bombycidae } & Ocinara albicollis \\
\hline & Trilocha friedelin \\
\hline Cossidae & Bergaris lutescens griseola \\
\hline \multirow[t]{5}{*}{ Erebidae: Aganainae } & Asota caricae \\
\hline & Asota egens \\
\hline & Asota producta \\
\hline & Mecodina lanceola \\
\hline & Neochera inops \\
\hline \multirow[t]{2}{*}{ Erebidae: Anominae } & Plecoptera recta \\
\hline & Rema costimaculata \\
\hline \multirow[t]{2}{*}{ Erebidae: Arctiinae } & Cyana malayensis \\
\hline & Cyana selangorica \\
\hline \multirow[t]{6}{*}{ Erebidae: Boletobiinae } & Saroba maculicosta \\
\hline & Sarobides inconclusa \\
\hline & Trichoblemma badia \\
\hline & Tamba lahera \\
\hline & Tamba lala \\
\hline & Tropidotamba lepraota \\
\hline Erebidae: Calpinae & Eudocima homaena \\
\hline \multirow[t]{12}{*}{ Erebidae: Erebinae } & Armana nigraericta \\
\hline & Avatha rufiscripta \\
\hline & Bastilla absentimacula \\
\hline & ?Buzara feneratrix \\
\hline & Ercheia cyllaria \\
\hline & Ercheia pulchrivenula \\
\hline & ?Ercheia sp. \\
\hline & Erygia spissa \\
\hline & Hypopyra pallidigera \\
\hline & Ischyja ferrifracta \\
\hline & ?Lygniodes schoenbergi \\
\hline & Ommatophora luminosa \\
\hline
\end{tabular}


Table 2. Continuation.

\begin{tabular}{|c|c|}
\hline Family: Subfamily & Species \\
\hline & Ophiusa trapezium \\
\hline & Parallelia arcuate \\
\hline & Pindara illibata \\
\hline & Platyja umminia \\
\hline & Sympis rufibasis \\
\hline & Sypna ?albilinea \\
\hline & Ugia signifera \\
\hline & Ugia sundana \\
\hline & ?Ugia sp. \\
\hline \multirow[t]{15}{*}{ Erebidae: Herminiinae } & Adrpsa ?ereboides \\
\hline & Bocula microscala \\
\hline & Bocula xanthostola \\
\hline & Bocula ?divergens \\
\hline & Erebus ephesperis ephesperis \\
\hline & Hadennia mysalis \\
\hline & Hypena similata \\
\hline & Schistorhynx argentistriga \\
\hline & Simplicia brevicosta \\
\hline & Simplicia discosticta \\
\hline & Simplicia cf. discosticta \\
\hline & Simplicia griseolimbalis \\
\hline & Simplicia rufa \\
\hline & Simplicia schaldusalis \\
\hline & Simplicia sp. \\
\hline Erebidae: Hypocalinae & Hypocala andamana \\
\hline \multirow[t]{8}{*}{ Erebidae: Lymantriinae } & Artornis obtuse \\
\hline & Arctornis plumbacea \\
\hline & Arctornis ungula \\
\hline & Arctornis sp. \\
\hline & Locharna limbata \\
\hline & Olene mendosa \\
\hline & Orvasca subnotata \\
\hline & Scarpona ennomoides \\
\hline
\end{tabular}


Table 2. Continuation.

\section{Family: Subfamily}

Erebidae: Pangraptinae

Erebidae: Scoliopteryginae

Erebidae: Tinoliinae

Erebidae: Miscellaneous genera

Erebidae: incertae sedis

Geometridae: Desmobathrinae

Geometridae: Ennominae

\section{Species}

Cultripalpa lunulifera

Masca abactalis

Throana klossi

Cosmophila scitipennis

Falana sordida

Poeta denotalis

Arthisma amissa

Oxyodes scrobiculata

Tamsia hieroglyphica

Xanthonomis xanthine

Asta sp.

Brontypena ochrocuprea

Flammona quadrifasciata

Hyperlopha discontenta

Marapana flavicosta

Alex palparia

Eumelea florinata

Eumelea ludovicata

?Hypulia sp. or Nadagara sp.

Borbacha altipardaria

Celenna festivaria

Fascellina castanea

Fascellina viridicosta

Hypomecis ?sommereri

Hypomecis sp.

Ophthalmitis rufilauta

Petelia medardaria

Petelia paroobathra

Plutodes malaysiana

Probithia exclusa

Probithia sp.

Racotis inconclusa 
Table 2. Continuation.

\begin{tabular}{|c|c|}
\hline Family: Subfamily & Species \\
\hline & Racotis sp. \\
\hline & Tasta micaceata \\
\hline & Zamarada balata \\
\hline & Zamarada sp. \\
\hline & Zeheba aureatoides \\
\hline \multirow[t]{7}{*}{ Geometridae: Geometrinae } & Agathia laetata \\
\hline & Agathia succedanea \\
\hline & Dysphania malayanus \\
\hline & Herochroma sp. \\
\hline & Ornithospila bipunctata \\
\hline & Ornithospila sp. \\
\hline & Spaniocentra megaspilaria \\
\hline Geometridae: Sterrhinae & Scopula (Antitrygodes) divisaria \\
\hline Geometridae & Thalassodes sp. \\
\hline \multirow[t]{7}{*}{ Lasiocampidae } & Cyclophragma basidiscata \\
\hline & Euthrix laeta \\
\hline & Kunugia basidiscata \\
\hline & Kunugia gynandra \\
\hline & Paralebeda lucifuga \\
\hline & Trabana ?krishna \\
\hline & Trabada viridana \\
\hline \multirow[t]{7}{*}{ Limacodidae } & Cania bandura \\
\hline & Cania minuta \\
\hline & Griseothosea cruda \\
\hline & Idonauton apicalis \\
\hline & Setora nitens \\
\hline & Thosea medialis \\
\hline & Thosea vetusta \\
\hline Noctuidae: Aventiinae & Cruxoruza geometrica \\
\hline Noctuidae: Noctuinae & Athetis sp. or Spodoptera sp. \\
\hline
\end{tabular}


Table 2. Continuation.

\section{Family: Subfamily}

Noctuidae: Pantheinae

Noctuidae: Stctopteryginae

Nolidae: Chloephorinae

Notodontidae

Pyralidae: Epipaschinae

Pyralidae: Pyralinae

Pyralidae: Pyraustinae

\section{Species}

Cyclodes omma

Donda striatovirens

Lophoptera squammigera

Stictoptera columba

Stictoptera semialba

Blenina donans

Diehlea tumida

Diehlea sp.

Xenochroa costiplaga

Xenochroa xanthia

Ambadra suriga

Cerasana anceps

Chadrisa bipars

Brykia horsfieldi

Saliocleta nonagrioides

Sp. indet.

Herculia marthalis

Arthroschista tricolora

?Bradina $\mathrm{sp}$.

Conogethes clioalis

Conogethes sp.

Crypsiptya coclesalis

Glyphodes bivitralis

Glyphodes canthusalis

Gluphodes stolalis

Glyphodes sp.

?Glyphodes sp.

Nacoleia charesalis

Nevrina procopia

Nosophora sp.

Parotis ?brocata

Parotis hilaris 
Table 2. Continuation.

\begin{tabular}{|c|c|}
\hline Family: Subfamily & Species \\
\hline & Parotis laceritalis \\
\hline & Parotis marginata \\
\hline & Parotis cf. marginata \\
\hline & Parotis squamopedalis \\
\hline & Parotis sp. \\
\hline & Piletocera sp. \\
\hline & Pitama hermesalis \\
\hline & Pleuroptya sp. \\
\hline & Rhimphalea trogusalis \\
\hline & Tyspanodes venosa \\
\hline \multirow[t]{3}{*}{ Pyralidae } & Gadessa nilusalis \\
\hline & Syllepte fabiusalis \\
\hline & Syllepte iophanes \\
\hline \multirow[t]{2}{*}{ Sphingidae } & Daphnusa ocellaris \\
\hline & Eupanacra regularis \\
\hline \multirow[t]{5}{*}{ Thyrididae } & Banisia flavidiscalis \\
\hline & Banisia myrtaea \\
\hline & Opula lepida \\
\hline & shoppe \\
\hline & Telechines vialis \\
\hline \multirow[t]{2}{*}{ Uranidae: Epipleminae } & Dysaethria quadricaudata \\
\hline & Dysaethria ?oriocharis \\
\hline \multirow[t]{2}{*}{ Uranidae } & Lyssa zampa \\
\hline & Micronia (Urapteroides) astheniata \\
\hline Zygaenidae: Chalcosiinae & Eucormopsis lampra \\
\hline
\end{tabular}




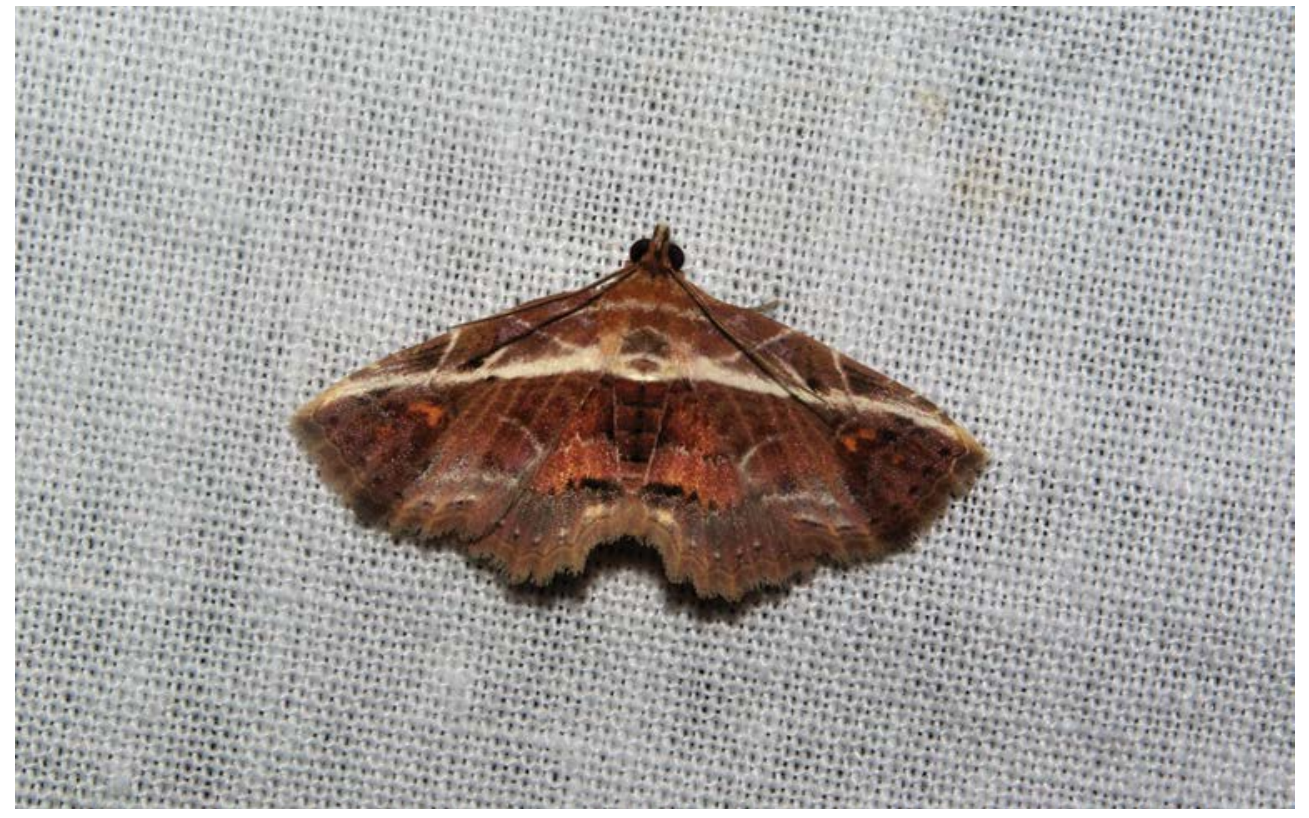

Fig. 1. Cruxoruza geometrica (Noctuidae: Aventiinae) is considered very rare in Southeast Asia. (Photo: R.Karam)

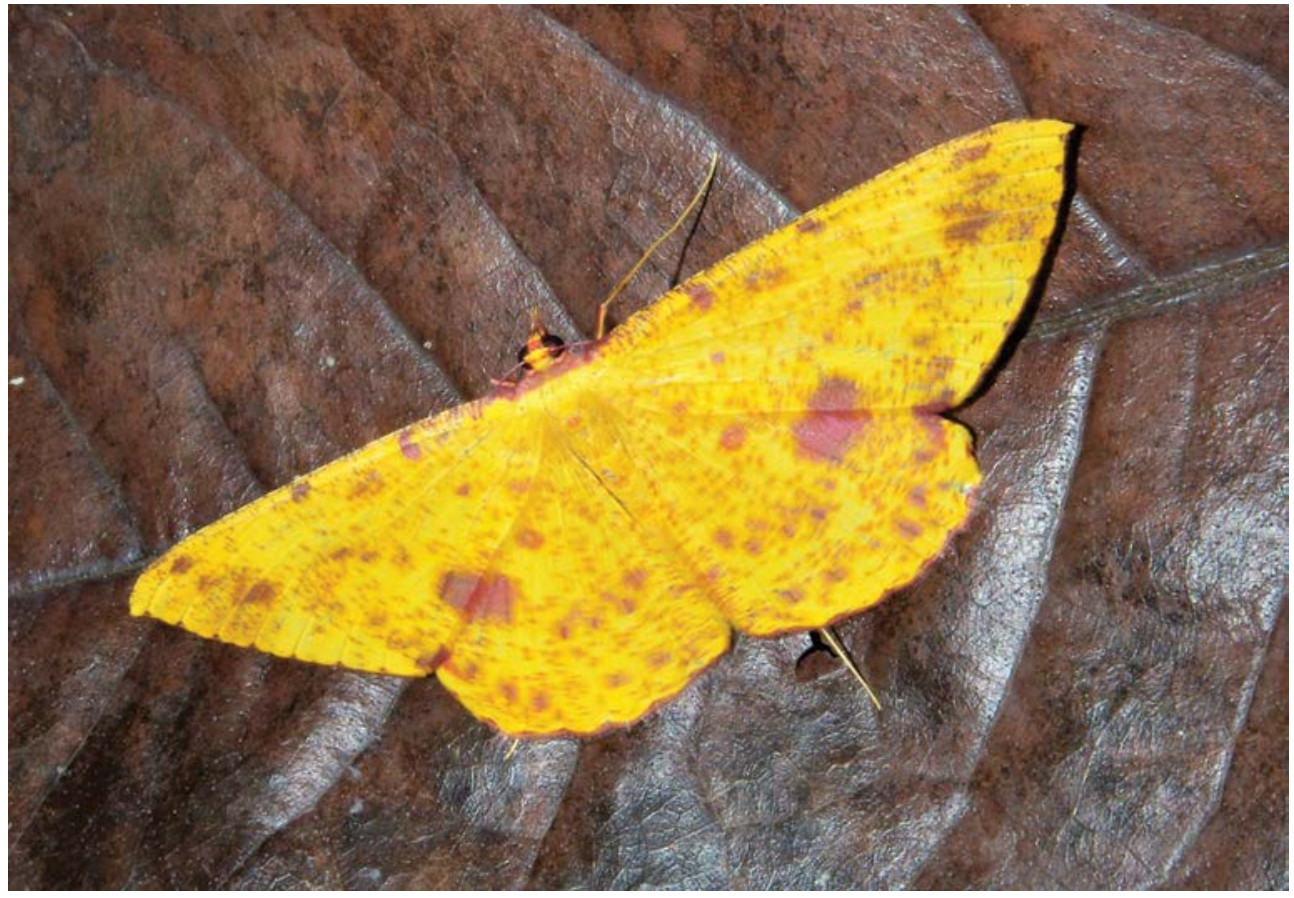

Fig. 2. The very rare Eumelea ludovicata (Geometridae: Desmobathrinae) will settle in the forest understorey. (Photo: R. Karam) 
represents. Not all moths are attracted to light traps, and bright ambient illumination throughout Singapore by night might interfere even with moths that are typically attracted to UV light traps. We attracted only two hawk moths although we found that elsewhere, such as in Bukit Brown cemetery, we attracted many more. We attracted one swallowtail moth Lyssa zampa although these are often very common in Singapore. Atlas moths are well known and very popular in this part of the world; we did not manage to attract even one atlas moth. The above observations are indicators that our trapping window did not record all of Singapore's species yet it did shed light on the potential number of moth species that Singapore may have.

Only one other systematic trapping study has been conducted in BTNR, by Koh (2007). She found 222 morphospecies in 12 sessions, which was nearly $40 \%$ more species than the next most diverse site at Nee Soon in the Central Catchment Nature Reserve. Her BTNR sample showed a larger total of individuals (47\% more than the next most populous site) and a higher Shannon diversity index than other sites in Singapore, but was outperformed on some other non-parametric measures of diversity (Koh, 2007). However, that study used different trapping equipment (black-light, automated trapping) and protocols, so the results are not directly comparable to ours. Our tally of 399 species over 22 sessions exceeds the anticipated total if Koh (2007) had continued trapping for a similar duration (based on visual comparison with her rarified species accumulation curve), but unlike her study we included micro moths in our totals.

The present study is the only one to provide a substantial body of species identifications for moths from BTNR. Together with trapping locations and information on vegetation zones, a baseline has been set for comparison with future studies that will be able to track performance and sustainability of the moth fauna in BTNR.

ACKNOWLEDGEMENTS. We would like to thank Dr Lena Chan who inspired the research and encouraged us to carry it through. We also would like to thank the National Parks Board who gave us the permit to set up our light trap and collect samples and, on many occasions, to transport our heavy generator across the reserve. The staff of the Bukit Timah Nature Reserve provided a great deal of help. A special thank you goes to Dr Henry Barlow who identified the moths for us and to Dr Geoffrey Davison who helped us tremendously in turning our article into a scientific format.

\section{References}

Barlow, H.S. (1982). An introduction to the moths of South East Asia. Kuala Lumpur: Malayan Nature Society.

Barlow, H.S. \& Wowoid, I.P. (1989). Moth diversity of a tropical rain forest in Peninsular Malaysia. J. Trop. Ecol. 5: 37-50. 
Beck, J. \& Linsenmair, K.E. (2006). Feasibility of light-trapping in community research on moths: attraction radius of light, completeness of samples, nightly flight times and seasonality of Southeast Asian hawkmoths (Lepidoptera: Sphingidae). J. Res. Lepidopt. 39: 18-37.

Chan, L. \& Davison, G.W.H. (2019). Introduction to the Comprehensive Biodiversity Survey of Bukit Timah Nature Reserve, Singapore, 2014-2018. Gard. Bull. Singapore 71 (Suppl. 1): 3-17

Falchi, F., Cinzano, P., Duriscoe, D., Kyba, C.C.M., Elvidge, C.M., Baugh, K., Portnoy, B.A., Rybnikova, N.A. \& Furgoni, R. (2016). The new world atlas of artificial night sky brightness. Sci. Adv. 2: e1600377.

Holloway, J.D. (1985). Moths as indicator organisms for categorising rain forest and monitoring changes and regeneration processes. In: Chadwick, A.C. \& Sutton, S.L. (eds) Tropical Rain Forest: The Leeds Symposium, pp. 235-242. Leeds: Leeds Philosophical and Literary Society.

Holloway, J.D. (1983-2010). The Moths of Borneo, vols. 1-18. Kuala Lumpur: Southdene Sdn. Bhd.

Kitching, R.L., Orr, A.G., Thalib, H., Mitchell, H., Hopkins, M.S. \& Graham, A.W. (2000). Moth assemblages as indicators of environmental quality in remnants of upland Australian rain forest. J. Appl. Ecol. 37: 284-297.

Koh, L.L. (2007). Moth diversity in Singapore - effects of forest fragmentation and correlation with butterfly diversity. B.Sc. thesis, National University of Singapore.

Leong, T.M., Murphy, P.V., Gan, C.W., d'Rozario, V. \& Strange, B.C. (2017). Marvellous moths of Fraser's Hill and other highlands of Peninsular Malaysia; a photographic memoir. Singapore: Mainland Press.

Murphy, D.H. (1973). Animals in the forest ecosystem. In: Chuang, S.H. (ed.) Animal Life and Nature in Singapore, pp. 53-73. Singapore: Singapore University Press.

Wallace, A.R. (1869). The Malay Archipelago: The land of the orang-utan, and the bird of paradise. A narrative of travel, with studies of man and nature. London: Macmillan and Co. 